\title{
PHYSICAL CLEANSING BIASES RECOGNITION PERFORMANCE FOR (IM)MORAL SOCIAL ISSUES
}

\author{
Kai KASPAR ${ }^{1,2}$, Christoph JAHN ${ }^{2}$ \\ ${ }^{1}$ Department of Psychology, University of Cologne \\ Richard-Strauss-Str. 2, 50931, Cologne, Germany \\ E-mail: kkaspar@uni-koeln.de \\ ${ }^{2}$ Institute of Psychology, University of Osnabrück \\ Seminarstraße 20, 49074, Osnabrück, Germany \\ E-mail: christoph.jahn@posteo.de
}

\begin{abstract}
Previous research showed that physical cleansing can affect moral judgements, indicating a functional link between the concepts of physical and moral purity. The act of cleansing one's own hands was also found to influence cognitive processes beyond the moral domain. Overall, research suggests that physical cleansing can bias cognitive information processing. To investigate this assumption, we extended the hitherto scope in this research line and examined cleanliness effects on memory performance. For the first time, we scrutinized the effect of hand cleansing on the recall and recognition performance for (im)moral social issues. We found that cleansing produced a significant increase in participants' memory for immoral versus moral social issues at the level of recognition performance, whereas free recall was not affected. This negativity bias occurred independently of whether cleansing was performed before or after the learning phase, indicating that cleansing has an effect on the retrieval of information from memory.
\end{abstract}

Key words: physical cleansing, memory performance, recognition, moral social issues, embodied cognition

\section{Introduction}

The Link between Physical and Moral Purity

Previous research showed that the impact of physical cleansing goes beyond the reduction of physical contamination. The no-

Authors' contributions

K. K. developed the study concept. K. K. and C. J. contributed to the study design. C. J. performed the data collection. K. K. performed the data analysis and interpretation. K. K. wrote the manuscript. C. J. approved the final version of the manuscript for submission. tion of a direct link between washing one's own body and moral purity is established in several religious ceremonies. It also became popular through William Shakespeare who described Lady Macbeth as being afflicted by a recurring need to wash her hands after the murder of King Duncan. Initial empirical evidence supported that a threat to one's moral purity evokes the urgent need to clean one's own body (Zhong \& Liljenquist, 2006). Since then, several experimental studies have been carried out to examine the range of morality-related causes as well as consequences of physical cleansing. It has been shown, on the one hand, that immoral behavior increases the desirability of cleans-

DOI: $10.21909 / \mathrm{sp} .2016 .04 .725$ 
ing-related products (Zhong \& Liljenquist, 2006; Lee \& Schwarz, 2010a). On the other hand, physical cleansing reduced the willingness to voluntarily help other persons after recalling an unethical deed of the past (Reuven, Liberman, \& Dar, 2014; Xu, Bègue, \& Bushman, 2014; Zhong \& Liljenquist, 2006). Obviously, hand cleansing can literally remove moral stains and restore one's moral self-image, making additional good deeds superfluous. This established link between physical and moral purity presumably derives from an ontogenetic process of concept coupling: while the concrete bodily state of physical purity is learned early in life, the abstract concept of moral purity may be built upon this sensorimotor experience later on (cf. Kaspar, Jurisch, \& Schneider, 2016). This explanation is in line with what the concept of embodied cognition suggests (cf. Wilson, 2002): bodily actions or states, such as physical purity, represent embodied cognitive information. Correspondingly, activating the concept of physical purity can affect the evaluation of immoral social issues. For example, Zhong, Strejcek, and Sivanathan (2010) found harsher judgments about immoral social issues after participants had washed their hands. Also, Kaspar and Klane (2016) found that hand cleansing led to harsher moral judgments about politicians who allegedly committed a misconduct. Hence, information about one's physical purity is an embodied information cue that effectively expands to abstract cognitions.

Physical Cleansing and the Clean Slate Effect

Moreover, effects of physical cleansing have also been reported beyond the moral domain. Xu, Zwick, and Schwarz (2012) found that the experience of good and bad luck can be metaphorically washed away, indicated by subsequent decision making strategies. Florack, Kleber, Busch, and Stöhr (2014) used hand washing to reduce consumers' biased perception of product features derived from ownership. Lee and Schwarz (2010b) showed that physical purity can reduce post-decisional dissonance as participants showed a reduced need to devaluate non-chosen options after hand washing. Finally, Kaspar (2013a) found an increased optimism regarding future performance in an anagram task when participants washed their hands after they had experienced failure in a preceding anagram task. All these effects indicate that physical cleansing can act as a very general ritual to close a matter (Kaspar, 2013a) and to induce a kind of a "clean slate" effect (Lee \& Schwarz, 2010b) whose impact cannot be explained by the moral-purity metaphor alone.

\section{Physical Cleansing and Information Pro- cessing}

But what is the mechanism behind such effects and what does it imply for moral judgments? Kaspar, Krapp, and König (2015) recently hypothesized that effects of physical cleansing (on moral behavior and in terms of clean slate phenomena) reflect a change in the weighting or selection of cognitive information. They concluded:

"The hitherto reported effects showed that the act of cleansing did not literally wash away what had already happened in the past. Instead, washing led to a specific (re-)weighting of the available information. For example, hand washing did not undo an unethical deed that participants had previously committed, did not change previous 
decisions, and did not substitute a failure experience by success, but it changed the weighting of unethical deeds, reduced the need to devaluate non-chosen options, and increased one's optimism to be more successful in the future, respectively" (p. 3).

Correspondingly, although referring to different assumptions and rules, several theoretical accounts unanimously highlight that cognitive information processing comprises weighting and integration procedures in the context of judgement formation and decision making (e.g., Skowronski \& Carlston, 1986; Anderson, 1990; Mandel \& Lehman, 1997). Consequently, we may assume that physical cleansing as well as cognitions about one's physical purity may systematically bias information processing.

To further scrutinize the idea of biased information processing by physical cleansing, we examined if physical cleansing affects memory for moral and immoral social issues. Thus, we extend the scope of previous studies to a central but hitherto neglected cognitive function in this field. However, given the mixed results of previous studies, two opposite mechanisms are conceivable:

On the one hand, we may assume that the perception of one's own physical purity leads to a higher sensitivity toward immorality and hence to a better memory performance for immoral versus moral items, because immorality is both a potential threat to one's own moral purity (Zhong \& Liljenquist, 2006) and a reference level to justify the image of oneself as a moral being. Indeed, Zhong et al. (2010) found that the activation of cleanliness cognitions was accompanied by an inflated moral self-image that, in turn, licenced harsher judgments about immoral social issues $^{1}$. Research in the field of emotions also supports the idea that being in a positive state (similar to the feeling of being morally clean) can bias information processing in favor of negative information: Schwager and Rothermund (2013) found an attentional preference for emotional stimuli that were opposite in valence to the current emotional state of the observer. Similarly, Parrott and Sabini (1990) found that participants in happy moods recalled more negative autobiographical memories than participants being in bad moods. In a more recent study by Kaspar, Gameiro, and König (2015) participants showed an attentional preference and a better recall performance for negative versus positive stimuli in general, which, however, was significantly stronger when participants were in positive mood compared to a negative mood. Finally, Das and Fennis (2008) found that a positive mood can increase attention for and processing of threatening information, "particularly when the information is self-relevant" (p. 221). Similarly, and with respect to the positive state of being physically and thus morally clean, we may assume an increased sensitivity toward negative items, reflected in a better memory performance for immoral social issues compared to moral social issues.

Alternatively, however, Cramwinckel, van Dijk, Scheepers, and van den Bos, (2013) observed that physical cleansing prevented

\footnotetext{
${ }^{1}$ Other researchers also reported less severe moral judgments after hand cleansing and after the cognitive activation of the concept of cleanliness (e.g., Schnall, Benton, \& Harvey, 2008). However, as recently outlined (cf. Kaspar, Krapp et al., 2015), these seemingly contradicting results might be explained by different attribution processes: harsher moral judgments are expected when cleanliness cognitions restore one's own moral self-image, whereas milder moral judgments are likely to occur when the state of cleanliness is attributed to the judged target.
} 
negative effects of a moral threat, whereby this effect was most pronounced in participants with a strong moral identity. This finding suggests a decreased (instead of an increased) sensitivity towards negative (immoral) information as such information may lose its threatening potential in light of an inflated moral self-image elicited by physical cleansing (Zhong et al., 2010). Moreover, the feelings-as-information framework by Schwarz (1990) suggests that being in a positive mood state may reduce one's motivation to explore the environment with respect to threatening cues due to an increased feeling of safety. Consequently, physical and thus moral purity may decrease one's sensitivity towards immoral items, reflected by a better memory performance for moral social issues relative to immoral social issues.

\section{The Present Hypotheses}

In sum, previous literature suggests two competing mechanisms. However, both have in common that they imply a biased information processing in relative terms but not an effect of physical cleansing on participants' absolute memory performance. Consequently, we hypothesized first:

H1: Hand cleansing, compared to no cleansing, does not change the total sum of recalled/recognized items.

The second hypothesis was formulated without specifying the effect direction due to the mixed literature reviewed above. However, we expected an interaction effect in any case:

H2: Hand cleansing, compared to no cleansing, biases the memory performance with respect to the target's valence: physical cleansing either elicits better memory performance for immoral items relative to moral items, or vice versa.

In order to capture different memory processes, we intended to measure the performance in a free recall task and in a recognition task. As pointed out by Bagozzi and Silk (1983), recall and recognition are distinct but also in some way overlapping aspects of memory. In the case of recognition, a piece of information is compared with the content of memory. In the case of free recall, a set of concepts (or stimuli) is activated first, and then the target stimulus is compared with this set of concepts. By considering both types of memory performance, we were able to check which kind of cognitive process is touched by physical cleansing. As no previous study has examined this issue, we had no specific hypothesis regarding a potentially different effect of cleansing on recall and recognition.

Moreover, Kaspar, Krapp et al. (2015) recently reported that hand cleansing affected moral judgements about visually depicted social scenes but that it did not show an effect on how their participants had scanned the visual stimuli before stimulus evaluation, as indicated by eye tracking data. The authors concluded that the impact of physical cleansing does not touch early processes of sensory information sampling. Instead, corresponding effects may reflect a true cognitive phenomenon. Hence, we might speculate that the effect of physical cleansing occurs later in the information processing stream. We aimed to provide further evidence for this claim. Therefore, in the present study, cleansing was applied before or after the learning phase. If the assumed effect of cleansing exclusively occurs when cleansing is performed before the learning phase, this will indicate that the effect of physical 
purity is temporally limited to the early stage of information sampling and encoding. It might be that this is the case with respect to memory performance, which differs remarkably from visual processing investigated by Kaspar, Krapp et al. (2015). In contrast, if the effect occurs when hands are cleansed after the learning phase, this will indicate that cleansing has an effect on the retrieval of information from memory. Thus, we specified $\mathrm{H} 2$ and tested the following two hypotheses:

$\mathrm{H} 2 \mathrm{a}$ : Hand cleansing before the learning phase elicits better memory performance for moral/immoral items relative to immoral/ moral items.

$\mathrm{H} 2 \mathrm{~b}$ : Hand cleansing after the learning phase elicits better memory performance for moral/immoral items relative to immoral/ moral items.

\section{Methods \\ Participants and Study Design}

Seventy-five university students $(57 \mathrm{fe}$ males) with a mean age of 21.98 years $(S D=$ $2.10)$ participated voluntarily. Due to our focal interaction hypothesis $\mathrm{H} 2$, we posited the sample size a priori following Xu et al. (2012) who reported an interaction effect between hand cleansing and a second between-subject factor (experienced good versus bad luck) on decision making. The authors tested a mean sample size of $n=14.75$ (Study 1) and $n=24.5$ (Study 2) per condition. Thus, we decided to test 25 participants per condition in the present study. Moreover, as the a priori estimation of effect sizes is a serious issue in psychological research, we conducted an a posteriori review of studies that investigated the main effect of a real cleans- ing (versus no cleansing) treatment on subsequent behavior and judgments in different domains. Appendix A presents an up-todate list of the effect sizes that might help planning future studies. We observed a mean effect size of $d=0.66(f=0.33)$, which corresponds to a total sample size of $n=72 / 21 / 27$ for the between/within/interaction effect of the present $3 \times 2$ mixed between-within design (see below) - given a significance level of .05, a desired power of .80, and a correlation between repeated measures of $r=.50$ (GPower 3; Faul, Erdfelder, Lang, \& Buchner, 2007). Thus, the sample size of the present study is in line with what the current state of research suggests. However, it should be noted that we focused on an interaction effect, whereas this mean effect size is mainly based on two-group comparisons. For a complete picture, we report the actually observed power and effect sizes in the result section.

Female participants were equally distributed across conditions because gender effects in free recall tasks had been previously reported (McGuinness, Olson, \& Chapman, 1990). To ensure high motivation of all participants in the memory test, the experimenter communicated to them that the best five performers will win 10 Euros. The participants were randomly assigned to one of three groups. Twenty-five participants formed the "cleansing before learning group" and 25 participants formed the "cleansing after learning group". The former group applied the hand cleansing treatment before the learning phase of the memory test, while the latter group cleansed their hands afterwards (but before the retrieval phase). A third group of 25 subjects formed the "control group" and did not cleanse their hands in accordance with previous studies (e.g., Zhong \& Liljenquist, 2006; Zhong et al., 2010, Kaspar, 
2013a). All participants were presented the same set of moral and immoral items, leading to a 3 (between-subject factor: group) $\times 2$ (within-subject factor: target valence) mixed between-within design.

\section{Stimuli}

Following Zhong et al. (2010), we used social issues in the form of written words. However, due to potential cross-cultural differences in morality perception, we pre-tested a new list of 62 items. An independent sample of 59 German participants ( 36 female; $M_{\text {age }}=$ 23.02, $S D_{\text {age }}=2.30$ ) drawn from the same population of university students rated all social issues on a scale ranging from 1 ( $m o r$ ally bad) to 9 (morally good). We selected 60 items for the main study; 30 items showed a mean morality rating that was more than two standard deviations above the grand mean; 30 items were rated more than two standard deviations below the grand mean. We ranked the items of the two lists according to their morality rating and assigned them in an alternate fashion to the set of target stimuli used in the learning phase (15 moral and 15 immoral stimuli) and to the set of distractors used for the recognition test. A complete list of all items is presented in Appendix B.

\section{Procedure}

After giving written informed consent, the participants were instructed to the procedure and task. The experimenter told them that they will perform a memory test first, followed by an unrelated product evaluation study. The latter was used to make the cover story and the cleansing manipulation plausible.

After the introduction, the experimenter asked the participants of the "cleansing be- fore learning group" to cleanse their hands by using an antiseptic wipe due to hygienic reasons (cf. Zhong \& Liljenquest, 2006; Xu et al., 2012), because they would haptically interact with products in the later product evaluation study. Before the memory test started, the experimenter once more emphasized the gain of 10 Euros for the best five performers. The participants sat in front of a Computer (Dell Vastro Notebook). After reading a standardized instruction, 30 target words (15 moral and 15 immoral social issues) were presented centered on the screen and in randomized order for 3 seconds each. A fixation cross preceded each target word and was displayed for 1 second.

After this learning phase, the participants performed a filler task. We used the $\mathrm{d} 2$ attention endurance test (Brickenkamp, 2002). This test is a pencil-and-paper letter-cancellation test consisting of 14 lines of 57 randomly mixed letters each (either "d" or "p"). Within 20 seconds for each line, the participants have to mark only the letter " $\mathrm{d}$ " and only when two dashes are arranged either individually or in pairs above and below it. Our participants had 4 minutes to process the first ten lines of this test.

After this filler task, participants of the "cleansing after learning group" were asked to cleanse their hands. In the following retrieval phase, we applied a free recall test first. The participants had to reproduce as many social issues as possible on a blank list in any order within four minutes. Then, the participants performed a yes/no forcedchoice recognition test (cf. Mather \& Carstensen, 2003) in which all 30 targets were randomly embedded in a set of 30 equally rated moral and immoral distractors (see above). The participants indicated for each item whether it had been displayed in the 
learning phase or not. No time limit was set for this task.

Afterwards, the short product evaluation study took place in accordance with the cover story. The participants had to touch and rate several medical products on the basis of their appearance before they were finally debriefed about the purpose of the study. After we had tested all participants, we determined the top five performers, contacted them, and handed over the monetary win.

\section{Results}

First, we analyzed the effect of group and target valence (moral versus immoral social issue) on participants' performance in the free recall test by means of a $3 \times 2$ (group $\times$ target valence) mixed-method ANOVA. A response was rated as valid when it perfectly matched the target item or when it was of synonym meaning. Two independent raters completely agreed regarding the response evaluation. Recall performance was corrected for guessing by dividing the number of correctly recalled (im)moral targets by the sum of correctly and falsely recalled items. In accordance with $\mathrm{H} 1$, we found no main effect of group, $F(2,72)=0.05, p=.950, \eta_{p}{ }^{2}<$ 0.01 , observed power $(o P)=.06$, but an effect of the target valence by trend, $F(2,72)=$ $3.36, p=.071, \eta_{p}^{2}=0.05, o P=.44$, with a slightly better recall of immoral compared to moral social issues. Contradicting $\mathrm{H} 2$, no interaction was found, $F(2,72)=0.51, p=.605$, $\eta_{p}{ }^{2}=0.01, o P=.13$. Also, the recall performance for moral and immoral targets showed only a marginally significant correlation, $r=$ $.22, p=.054$.

In the next step, we analyzed the recognition performance and computed a $3 \times 2$ (group $\times$ target valence) mixed-method ANOVA.
Memory effects were quantified by $d$ ' in order to account for acquiescence biases (Stanislaw \& Todorov, 1999). The recognition performance for moral and immoral targets was positively correlated, $r=.66, p<$ .001. Again, we found no effect of group, $F(1,72)=0.04, p=.958, \eta_{p}{ }^{2}<0.01, o P=.06$. Moreover, one-way ANOVAs showed that there was neither a simple main effect of group on the recognition performance for moral targets, $F(2,72)=0.91, p=.406, \eta_{p}{ }^{2}=$ $0.03, o P=.20$, nor a simple main effect of group on the recognition performance for immoral targets, $F(2,72)=0.37, p=.692, \eta_{p}^{2}=$ $0.01, o P=.11$. Consequently, the cleansing treatment did not show a main effect when focusing on the aggregated levels of the factor "target valence", supporting H1 according to which physical cleansing does not change the total sum of recognized items. Moreover, cleansing did also not show simple main effects when focusing on the individual levels of target valence.

However, the two-way ANOVA revealed a main effect of target valence, $F(1,72)=26.26$, $p<.001, \eta_{p}{ }^{2}=0.27, o P>.99$, and an interaction, $F(1,72)=3.72, p=.029, \eta_{p}^{2}=0.09, o P=$ .66 , supporting $\mathrm{H} 2$. More specifically, $t$-tests for pairwise comparisons of target valence (moral versus immoral social issues) revealed a simple main effect in the "cleansing before learning group" $(\mathrm{H} 2 \mathrm{a}), t(24)=4.37, p<.001$, $d=0.87, o P=.99$, and in the "cleansing after learning group" $(\mathrm{H} 2 \mathrm{~b}), t(24)=3.07, p=.005$, $d=0.61, o P=.84$. As shown by Figure 1 , immoral targets (before cleansing: $M=2.52$, $S D=0.73$; after cleansing: $M=2.42, S D=$ $0.93)$ were better recognized than moral targets (before cleansing: $M=1.96, S D=0.77$; after cleansing: $M=2.02, S D=0.73$ ) in both groups. No effect occurred in the control group, $t(24)=1.06, p=.301, d=0.21, o P=.18$. 


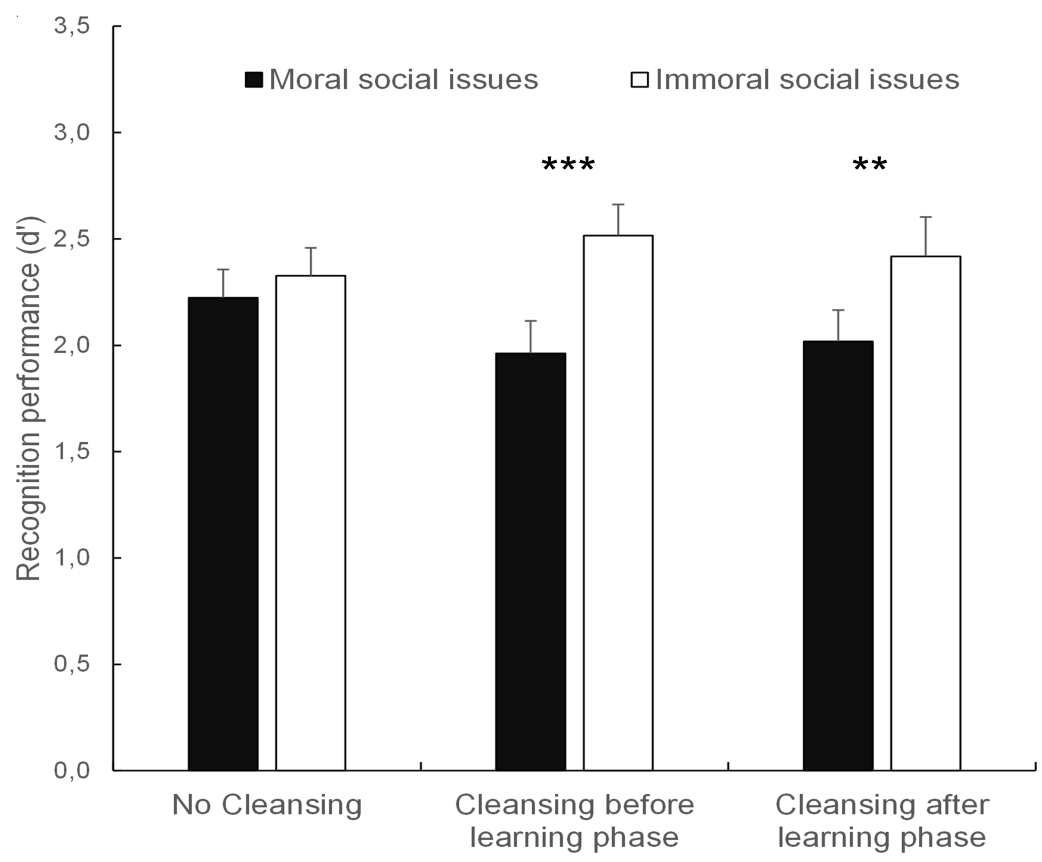

Note. ${ }^{* * *} p<.001, * * p<.01$

Figure 1 The effect of treatment group and target valence on recognition performance $(d ')$. Vertical lines indicate the standard error of the mean

Accordingly, the $95 \%$ confidence interval $(C I)$ for the difference between means showed that zero was included in the control group (95\% CI, -0.30 to 0.10$)$, whereas in the "cleansing before learning group" (95\% CI, -0.82 to -0.29$)$ and "cleansing after learning group" ( $95 \%$ CI, -0.67 to -0.13$)$ zero was not included. To sum up, we found support for $\mathrm{H} 2$ as hand cleansing elicited better memory performance for immoral targets relative to moral targets. In contrast, there was no difference between moral and immoral targets in the control condition.

Moreover, this result pattern indicates that the expected effect of hand cleansing oc- curred independently of the point in time when cleansing was performed, although the effect sizes suggest that the recognition bias was bigger when hands had been cleansed before the learning phase. However, when computing the $95 \%$ confidence interval for the bigger effect size (cf. Fritz, Morris, \& Richler, 2012), we found that the smaller effect size $(d=0.61)$ was within this confidence interval, $95 \% C I_{d}=0.29$ to 1.45 . That is, cleansing before or after the learning phase had a similar effect on memory.

To conclude, physical cleansing did not change the total sum of recognized items, as stated in H1. Instead, and in accordance with 
$\mathrm{H} 2$, physical cleansing elicited a negativity bias in the recognition performance (and no positivity bias) independently of whether it was applied before or after the learning phase. However, in the preceding recall test, no effect of the cleansing treatment was found.

\section{Discussion}

Previous research showed that physical cleansing does not only remove dirt from the body but that it also affects moral judgments (Schnall, Benton, \& Harvey, 2008; Zhong et al., 2010), one's moral self-image (Zhong et al., 2010) and moral behavior (Reuven et al., 2014), as well as several other mental functions such as decision making (Xu et al., 2012), justification of recent choices (Lee \& Schwarz, 2010b), optimism (Kaspar, 2013a), and product evaluation (Florack et al., 2014). Based on the assumption that all these effects are grounded on a specific (re-)weighting of cognitive information by the act of physical cleansing, we extended the hitherto scope to memory for (im)moral items.

We found that the performance in a free recall test was not affected by the cleansing manipulation, whereas hand cleansing influenced participants' recognition performance. As expected, an interaction between the cleansing condition and the target valence occurred. Cleansing compared to no cleansing led to a significant and medium-to largesized difference in the number of recognized targets, whereby immoral social issues were better recognized than moral ones. This valence effect occurred independently of whether cleansing was performed before or after the learning phase, but the effect was absent in the control group that did not cleanse the hands. This result pattern is in line with the findings reported by Kaspar, Krapp et al. (2015) who found an effect of hand cleansing on social judgments but no effect on visual information sampling as indicated by eye movement behavior on pictorial social scenes. The results of both studies contradict the notion that the effect of physical purity is temporally limited to the early stage of information sampling and encoding. Rather, the findings are more compatible with the view that hand cleansing affects purely cognitive mechanisms such as judgment formation (Kaspar, Krapp et al., 2015) or the retrieval of information from memory (present study). Indeed, it is plausible that the present cleansing effect reflects a change in the retrieval of information that appears to be independent of the point in time when cleansing is performed. However, we cannot exclude the possibility that hand cleansing at least partially influenced information sampling and encoding when it was performed before the learning phase. Thus, based on the present data, we cannot draw a final conclusion but we can definitely exclude that physical cleansing exclusively affects information sampling and encoding processes, because hand cleansing also influenced participants' recognition performance when cleansing was applied some minutes after the learning phase.

But why did the effect of cleansing not affect the performance in the free recall test? The present results suggest that cleansing does not modulate the activation of a set of concepts that is subsequently compared with the target stimulus. Instead, it seems that cleansing only biases the salience of moral and immoral targets when it comes to the recognition of what has been previously seen. We speculate that bodily experiences (i.e., physical purity) activates conceptually 
related abstract cognitions (i.e., about one's moral self-image), as suggested by numerous studies on embodiment phenomena (e.g., Ackerman, Nocera, \& Bargh, 2010; Kaspar, 2013b; Kaspar \& Krull, 2013; Kaspar, Jurisch et al., 2015). In this process, information about immoral issues is presumably prioritized and hence easier to recognize. It might be that this effect is driven by attention; that is, the state of physical purity might sensitize humans to those issues that are a threat to one's moral purity (Zhong \& Liljenquist, 2006). The present results appear to be more compatible with this view, whereas they contradict the notion that a clean state buffers threatening cues in favor of moral cues, as suggested by the findings of Cramwinckel et al. (2013). Thus, more research is necessary to better understand the context-dependency of cleansing-related effects on higher cognitions.

Overall, the present novel findings support the assumption that physical cleansing affects the cognitive weighting of task-relevant information. This result highlights that physical cleansing is correctly discussed in the light of embodied cognition. Cleansing is a specific sensorimotor input serving as embodied information about purity. This information significantly modulates higher cognitive processes.

Received March 17, 2016

\section{References}

Ackerman, J. M., Nocera, C. C., \& Bargh, J. A. (2010). Incidental haptic sensations influence social judgments and decisions. Science, 328, 1712-1715.

Anderson, N. H. (1990). A cognitive theory of judgment and decision. In N. H. Anderson (Ed.), Contributions to information integration theory (pp. 105-142). Hillsdale, NJ: Erlbaum.
Bagozzi, R. P., \& Silk, A. J. (1983). Recall, recognition, and the measurement of memory for print advertisements. Marketing Science, 2, 95-134.

Brickenkamp, R. (2002). Test d2: AufmerksamkeitsBelastungs-Test; Manual. Hogrefe, Verlag für Psychologie.

Cramwinckel, F. M., van Dijk, E., Scheepers, D., \& van den Bos, K. (2013). The threat of moral refusers for one's self-concept and the protective function of physical cleansing. Journal of Experimental Social Psychology, 49, 1049-1058.

Das, E., \& Fennis, B. M. (2008). In the mood to face the facts: When a positive mood promotes systematic processing of self-threatening information. Motivation and Emotion, 32, 221-230.

Faul, F., Erdfelder, E., Lang, A. G., \& Buchner, A. (2007). G*Power 3: A flexible statistical power analysis program for the social, behavioral, and biomedical sciences. Behavior Research Methods, 39, 175-191.

Fayard, J. V., Bassi, A. K., Bernstein, D. M., \& Roberts, B. W. (2009). Is cleanliness next to godliness? Dispelling old wives' tales: Failure to replicate Zhong and Liljenquist (2006). Journal of Articles in Support of the Null Hypothesis, 6, 2130 .

Florack, A., Kleber, J., Busch, R., \& Stöhr, D. (2014). Detaching the ties of ownership: The effects of hand washing on the exchange of endowed products. Journal of Consumer Psychology, 24, 284289.

Fritz, C. O., Morris, P. E., \& Richler, J. J. (2012). Effect size estimates: Current use, calculations, and interpretation. Journal of Experimental Psychology: General, 141, 2-18.

Johnson, D. J., Cheung, F., \& Donnellan, M. B. (2014). Does cleanliness influence moral judgments? A direct replication of Schnall, Benton, and Harvey (2008). Social Psychology, 45, 209215.

Kaspar, K. (2013a). Washing one's hands after failure enhances optimism but hampers future performance. Social Psychological and Personality Science, 4, 69-73.

Kaspar, K. (2013b). A weighty matter: Heaviness influences the evaluation of disease severity, drug effectiveness, and side effects. PloS ONE, 8, e78307.

Kaspar, K., Gameiro, R. R., \& König, P. (2015). Feeling good, searching the bad: Positive priming increases attention and memory for negative stimuli on webpages. Computers in Human Behavior, 53, 332-343. 
Kaspar, K., Jurisch, A., \& Schneider, M. (2016). Embodied cognition and humor: The impact of weight sensations on humor experience and the moderating role of gender. Current Psychology, 35, 377-385.

Kaspar, K., \& Klane, A. (2016). Embodied information affects judgments about politicians: The impact of haptic weight sensations and hand cleansing. International Journal of Psychology, online first, 1-9.

Kaspar, K., Krapp, V., \& König, P. (2015). Hand washing induces a clean slate effect in moral judgments: A pupillometry and eye-tracking study. Scientific Reports, 5, Article 10471.

Kaspar, K., \& Krull, J. (2013). Incidental haptic stimulation in the context of flirt behavior. Jour nal of Nonverbal Behavior, 37, 165-173.

Lee, S. W. S., \& Schwarz, N. (2010a). Dirty hands and dirty mouths: Embodiment of the moralpurity metaphor is specific to the motor modality involved in moral transgression. Psychological Science, 21, 1423-1425.

Lee, S. W. S., \& Schwarz, N. (2010b). Washing away postdecisional dissonance. Science, 328 , 709-709.

Lobel, T. E., Cohen, A., Shahin, L. K., Malov, S., Golan, Y., \& Busnach, S. (2015). Being clean and acting dirty: The paradoxical effect of self-cleansing. Ethics \& Behavior, 25, 307-313.

Mandel, D. R., \& Lehman, D. R. (1998). Integration of contingency information in judgments of cause, covariation, and probability. Journal of Experimental Psychology: General, 127, 269. 285.

McGuinness, D., Olson, A., \& Chapman, J. (1990). Sex differences in incidental recall for words and pictures. Learning and Individual Differences, 2, 263-285

Mather, M., \& Carstensen, L. L. (2003). Aging and attentional biases for emotional faces. Psychological Science, 14, 409-415.

Parrott, W. G., \& Sabini, J. (1990). Mood and memory under natural conditions: Evidence for mood incongruent recall. Journal of personality and Social Psychology, 59, 321-336.

Reuven, O., Liberman, N., \& Dar, R. (2014). The effect of physical cleaning on threatened moral- ity in individuals with obsessive-compulsive disorder. Clinical Psychological Science, 2, 224229.

Schnall, S., Benton, J., \& Harvey, S. (2008). With a clean conscience cleanliness reduces the severity of moral judgments. Psychological Science, 19, 1219-1222.

Schwager, S., \& Rothermund, K. (2013). Counterregulation triggered by emotions: Positive/negative affective states elicit opposite valence biases in affective processing. Cognition \& Emotion, 27, 839-855.

Schwarz, N. (2001). Feelings as information: Implications for affective influences on information processing. In L. L. Martin \& G. L. Clore (Eds.), Theories of mood and cognition: A user's handbook (pp. 159-176). Mahwah, NJ: Erlbaum.

Skowronski, J. J., \& Carlston, D. E. (1987). Social judgment and social memory: The role of cue diagnosticity in negativity, positivity, and extremity biases. Journal of Personality and Social Psychology, 52, 689-699.

Stanislaw, H., \& Todorov, N. (1999). Calculation of signal detection theory measures. Behavior Research Methods, Instruments, \& Computers, 31, 137-149.

Wilson, M. (2002). Six views of embodied cognition. Psychonomic Bulletin \& Review, 9, 625636.

Xu, A. J., Zwick, R., \& Schwarz, N. (2012). Washing away your (good or bad) luck: Physical cleansing affects risk-taking behavior. Journal of Experimental Psychology. General, 141, 2630 .

Xu, H., Bègue, L., \& Bushman, B. J. (2014). Washing the guilt away: Effects of personal versus vicarious cleansing on guilty feelings and prosocial behavior. Frontiers in Human Neuroscience, 8, Article 97, 1-5.

Zhong, C., \& Liljenquist, K. (2006). Washing away your sins: Threatened morality and physical cleansing. Science, 313, 1451-1452.

Zhong, C., Strejcek, B., \& Sivanathan, N. (2010). A clean self can render harsh moral judgment. Journal of Experimental Social Psychology, 46, 859862 . 


\section{Appendix A}

Effect sizes extracted from published studies that compared the effect of a physical cleansing condition with the effect of a no cleansing condition on subsequent behavior or judgments

\begin{tabular}{|c|c|c|c|c|c|c|}
\hline Author(s) & Study & Measurement & $\begin{array}{c}M_{\text {clean }} \\
(S D)\end{array}$ & $\begin{array}{l}M_{\text {control }} \\
(S D)\end{array}$ & $\begin{array}{c}\text { Cohen's } \\
d\end{array}$ & Remark \\
\hline $\begin{array}{l}\text { Fayard et al. } \\
(2009)\end{array}$ & 2 & $\begin{array}{l}\text { Willingness to } \\
\text { help }\end{array}$ & $\begin{array}{l}10.33 \\
(8.12)\end{array}$ & $\begin{array}{l}10.67 \\
(8.84)\end{array}$ & 0.04 & $\begin{array}{l}\text { Amount of time } \\
\text { volunteered }\end{array}$ \\
\hline $\begin{array}{l}\text { Florack et al. } \\
\text { (2014) }\end{array}$ & 1 & $\begin{array}{c}\text { Probability of } \\
\text { product exchange }\end{array}$ & --- & --- & 0.73 & $\begin{array}{c}\text { Odds ratio was } \\
0.264\end{array}$ \\
\hline $\begin{array}{l}\text { Florack et al. } \\
(2014)\end{array}$ & 2 & $\begin{array}{l}\text { Probability of } \\
\text { product exchange }\end{array}$ & --- & --- & 0.53 & $\begin{array}{c}\text { Odds ratio was } \\
0.381\end{array}$ \\
\hline $\begin{array}{l}\text { Florack et al. } \\
\text { (2014) }\end{array}$ & 3 & $\begin{array}{c}\text { Probability of } \\
\text { product exchange }\end{array}$ & --- & --- & 0.80 & $\begin{array}{l}\text { Odds ratio was } \\
\quad 0.236\end{array}$ \\
\hline $\begin{array}{l}\text { Florack et al. } \\
\text { (2014) }\end{array}$ & 3 & $\begin{array}{l}\text { Evaluation of } \\
\text { products }\end{array}$ & $\begin{array}{c}6.27 \\
(1.27)\end{array}$ & $\begin{array}{c}5.52 \\
(1.18)\end{array}$ & 0.61 & $\begin{array}{c}\text { Mean across } \\
\text { owned and not } \\
\text { owned product }\end{array}$ \\
\hline $\begin{array}{l}\text { Johnson et al. } \\
\text { (2014) }\end{array}$ & 2 & $\begin{array}{l}\text { Judged severity } \\
\text { of immoral } \\
\text { behavior }\end{array}$ & $\begin{array}{c}5.66 \\
(0.59)\end{array}$ & $\begin{array}{c}5.65 \\
(0.68)\end{array}$ & 0.02 & $\begin{array}{c}\text { Physical } \\
\text { cleansing after } \\
\text { experiencing } \\
\text { disgust } \\
\end{array}$ \\
\hline $\begin{array}{l}\text { Kaspar } \\
(2013 a)\end{array}$ & 1 & $\begin{array}{l}\text { Optimism after } \\
\text { failure in a task }\end{array}$ & $\begin{array}{c}1.21 \\
(1.36)\end{array}$ & $\begin{array}{c}0.47 \\
(1.14)\end{array}$ & 0.59 & $\begin{array}{c}\text { Increased } \\
\text { optimism after } \\
\text { hand cleansing }\end{array}$ \\
\hline $\begin{array}{l}\text { Kaspar } \\
(2013 a)\end{array}$ & 1 & $\begin{array}{c}\text { Cognitive } \\
\text { performance }\end{array}$ & $\begin{array}{c}8.36 \\
(2.86)\end{array}$ & $\begin{array}{l}10.81 \\
(3.35)\end{array}$ & 0.79 & $\begin{array}{l}\text { Reduced } \\
\text { performance } \\
\text { after hand } \\
\text { cleansing }\end{array}$ \\
\hline $\begin{array}{l}\text { Lee \& } \\
\text { Schwarz } \\
(2010 a)\end{array}$ & 1 & $\begin{array}{l}\text { Change in } \\
\text { product } \\
\text { preference }\end{array}$ & --- & --- & $0.84 *$ & $\begin{array}{c}\text { Cognitive } \\
\text { dissonance } \\
\text { (control) versus } \\
\text { clean slate effect } \\
\text { (clean) }\end{array}$ \\
\hline
\end{tabular}

Appendix A continues 
Appendix A continued

\begin{tabular}{|c|c|c|c|c|c|c|}
\hline $\begin{array}{l}\text { Lee \& } \\
\text { Schwarz } \\
(2010 a)\end{array}$ & 2 & $\begin{array}{l}\text { Change in } \\
\text { product } \\
\text { preference }\end{array}$ & --- & --- & $0.61^{*}$ & $\begin{array}{c}\text { Cognitive } \\
\text { dissonance } \\
\text { (control) versus } \\
\text { clean slate effect } \\
\text { (clean) } \\
\end{array}$ \\
\hline $\begin{array}{l}\text { Lobel et al. } \\
(2015)\end{array}$ & 1 & $\begin{array}{l}\text { Level of cheating } \\
\text { in a test }\end{array}$ & $\begin{array}{c}5.40 \\
(1.72)\end{array}$ & $\begin{array}{c}4.27 \\
(0.88)\end{array}$ & 0.83 & $\begin{array}{l}\text { Level of cheating } \\
\text { after (clean) vs. } \\
\text { before (control) } \\
\text { taking a shower }\end{array}$ \\
\hline $\begin{array}{l}\text { Lobel et al. } \\
(2015)\end{array}$ & 2 & $\begin{array}{l}\text { Amount of } \\
\text { donation }\end{array}$ & $\begin{array}{l}2.05 \\
(2.47)\end{array}$ & $\begin{array}{c}4.43 \\
(7.13)\end{array}$ & 0.45 & $\begin{array}{l}\text { Amount of } \\
\text { donation before } \\
\text { (control) vs. after } \\
\text { (clean) visiting } \\
\text { the mikveh }\end{array}$ \\
\hline $\begin{array}{l}\text { Reuven et al. } \\
(2014)\end{array}$ & 1 & $\begin{array}{l}\text { Willingness to } \\
\text { help }\end{array}$ & $\begin{array}{c}1.57 \\
(0.65)\end{array}$ & $\begin{array}{c}2.00 \\
(0.38)\end{array}$ & 0.81 & $\begin{array}{l}\text { The effect was } \\
\text { even larger in } \\
\text { participants with } \\
\text { OCD }(d=7.02)\end{array}$ \\
\hline $\begin{array}{l}\text { Schnall et al. } \\
(2008)\end{array}$ & 2 & $\begin{array}{l}\text { Judged severity } \\
\text { of immoral } \\
\text { behavior }\end{array}$ & $\begin{array}{l}4.73 \\
(0.95)\end{array}$ & $\begin{array}{c}5.43 \\
(0.67)\end{array}$ & 0.85 & $\begin{array}{c}\text { Physical } \\
\text { cleansing after } \\
\text { experiencing } \\
\text { disgust }\end{array}$ \\
\hline $\begin{array}{l}\text { Xu et al. } \\
\text { (2014) }\end{array}$ & 1 & $\begin{array}{l}\text { Willingness to } \\
\text { help }\end{array}$ & $\begin{array}{c}0.24 \\
(0.54)\end{array}$ & $\begin{array}{c}2.36 \\
(2.08)\end{array}$ & 1.41 & $\begin{array}{l}\text { Number of } \\
\text { questionnaires } \\
\text { returned }\end{array}$ \\
\hline $\begin{array}{l}\text { Zhong \& } \\
\text { Liljenquist } \\
(2006)\end{array}$ & 4 & $\begin{array}{l}\text { Willingness to } \\
\text { help }\end{array}$ & --- & --- & 0.78 & $\begin{array}{l}\text { Hand cleansing } \\
\text { after recalling an } \\
\text { unethical deed of } \\
\text { the past; odds } \\
\text { ratio was } .244\end{array}$ \\
\hline $\begin{array}{l}\text { Zhong et al. } \\
(2010)\end{array}$ & 1 & $\begin{array}{l}\text { Moral judgments } \\
\text { about social } \\
\text { issues }\end{array}$ & $\begin{array}{l}-2.62 \\
(1.30)\end{array}$ & $\begin{array}{l}-1.85 \\
(1.46)\end{array}$ & 0.56 & $\begin{array}{l}\text { The rating scale } \\
\text { ranged from }-5 \\
\text { (very immoral) to } \\
5 \text { (very moral) }\end{array}$ \\
\hline
\end{tabular}

Note. We calculated adjusted effect sizes when groups differed in sample size. In the case of no information about group sizes, we assumed equally sized groups. *Effect size for interaction effect 


\section{Appendix B}

Moral and immoral items presented in the learning phase (targets) and retrieval phase (targets plus distractors) of the memory test (English translations and German originals).

\begin{tabular}{|c|c|c|c|}
\hline \multicolumn{2}{|c|}{ Targets } & \multicolumn{2}{|c|}{ Distractors } \\
\hline moral & immoral & moral & immoral \\
\hline $\begin{array}{l}\text { Kissing } \\
\text { (Küssen) }\end{array}$ & $\begin{array}{c}\text { Racism } \\
\text { (Rassismus) }\end{array}$ & $\begin{array}{c}\text { Charity } \\
\text { (Nächstenliebe) }\end{array}$ & $\begin{array}{c}\text { Theft } \\
\text { (Diebstahl) }\end{array}$ \\
\hline $\begin{array}{l}\text { Respect } \\
\text { (Respekt) }\end{array}$ & $\begin{array}{c}\text { Abortion } \\
\text { (Abtreibung) }\end{array}$ & $\begin{array}{l}\text { Fidelity } \\
\text { (Treue) }\end{array}$ & $\begin{array}{c}\text { Rape } \\
\text { (Vergewaltigung) }\end{array}$ \\
\hline $\begin{array}{l}\text { Loyalty } \\
\text { (Loyalität) }\end{array}$ & $\begin{array}{l}\text { Pornography } \\
\text { (Pornographie) }\end{array}$ & $\begin{array}{c}\text { Modesty } \\
\text { (Bescheidenheit) }\end{array}$ & $\begin{array}{l}\text { Lying } \\
\text { (Lügen) }\end{array}$ \\
\hline $\begin{array}{l}\text { Honesty } \\
\text { (Ehrlichkeit) }\end{array}$ & $\begin{array}{l}\text { Mobbing } \\
\text { (Mobbing) }\end{array}$ & $\begin{array}{c}\text { Courtesy } \\
\text { (Höflichkeit) }\end{array}$ & $\begin{array}{c}\text { Egoism } \\
\text { (Egoismus) }\end{array}$ \\
\hline $\begin{array}{l}\text { Fairness } \\
\text { (Gerechtigkeit) }\end{array}$ & $\begin{array}{l}\text { Corruption } \\
\text { (Korruption) }\end{array}$ & $\begin{array}{c}\text { Solacing } \\
\text { (Trost spenden) }\end{array}$ & $\begin{array}{l}\text { Violence } \\
\text { (Gewalt) }\end{array}$ \\
\hline $\begin{array}{l}\text { Praising } \\
\text { (Loben) }\end{array}$ & $\begin{array}{l}\text { Blasphemy } \\
\text { (Lästern) }\end{array}$ & $\begin{array}{l}\text { Tolerance } \\
\text { (Toleranz) }\end{array}$ & $\begin{array}{c}\text { Cheating } \\
\text { (Schummeln) }\end{array}$ \\
\hline $\begin{array}{l}\text { Fair Play } \\
\text { (Fair Play) }\end{array}$ & $\begin{array}{c}\text { Food waste } \\
\text { (Verschwendung von } \\
\text { Nahrungsmitteln) }\end{array}$ & $\begin{array}{c}\text { Generosity } \\
\text { (Großzügigkeit) }\end{array}$ & $\begin{array}{l}\text { Laziness } \\
\text { (Faulheit) }\end{array}$ \\
\hline $\begin{array}{l}\text { Forgiving } \\
\text { (Verzeihen) }\end{array}$ & $\begin{array}{c}\text { Tax evasion } \\
\text { (Steuerhinterziehung) }\end{array}$ & $\begin{array}{c}\text { Helpfulness } \\
\text { (Hilfsbereitschaft) }\end{array}$ & $\begin{array}{c}\text { Vandalism } \\
\text { (Vandalismus) }\end{array}$ \\
\hline $\begin{array}{l}\text { Masturbation } \\
\text { (Masturbation) }\end{array}$ & $\begin{array}{c}\text { Pollution } \\
\text { (Umweltverschmutzung) }\end{array}$ & $\begin{array}{c}\text { Giving a tip } \\
\text { (Trinkgeld geben) }\end{array}$ & $\begin{array}{l}\text { Prostitution } \\
\text { (Prostitution) }\end{array}$ \\
\hline $\begin{array}{l}\text { Homosexuality } \\
\text { (Homosexualität) }\end{array}$ & $\begin{array}{l}\text { Unpunctuality } \\
\text { (Unpünktlichkeit) }\end{array}$ & $\begin{array}{l}\text { Nursing care } \\
\text { (Altenpflege) }\end{array}$ & $\begin{array}{l}\text { Wearing furs } \\
\text { (Pelze tragen) }\end{array}$ \\
\hline $\begin{array}{l}\text { Waste separation } \\
\text { (Mülltrennung) }\end{array}$ & $\begin{array}{l}\text { Discrimination } \\
\text { (Diskriminierung) }\end{array}$ & $\begin{array}{c}\text { Making gifts } \\
\text { (Geschenke machen) }\end{array}$ & $\begin{array}{c}\text { Drink-driving } \\
\text { (Alkohol am Steuer) }\end{array}$ \\
\hline $\begin{array}{l}\text { Youth protection } \\
\text { (Jugendschutz) }\end{array}$ & $\begin{array}{c}\text { Pirated Copying } \\
\text { (Raubkopien anfertigen) }\end{array}$ & $\begin{array}{l}\text { Thoughtfulness } \\
\text { (Rücksichtname) }\end{array}$ & $\begin{array}{c}\text { Waste of water } \\
\text { (Wasserverschmutzung) }\end{array}$ \\
\hline $\begin{array}{l}\text { Saving electricity } \\
\text { (Strom sparen) }\end{array}$ & $\begin{array}{l}\text { Being unfaithful } \\
\text { (Fremdgehen) }\end{array}$ & $\begin{array}{l}\text { Adopting a child } \\
\text { (Adoptieren) }\end{array}$ & $\begin{array}{l}\text { Vulgar language } \\
\text { (vulgäre Sprache) }\end{array}$ \\
\hline
\end{tabular}


Appendix B continued

\begin{tabular}{lccc}
\hline \multicolumn{1}{c}{ Targets } & \multicolumn{2}{c}{ Distractors } \\
moral & immoral & moral & immoral \\
\hline $\begin{array}{l}\text { Equal opportunity } \\
\text { (Chancengleichheit) }\end{array}$ & $\begin{array}{c}\text { Illegal employment } \\
\text { (Schwarzarbeit) }\end{array}$ & $\begin{array}{c}\text { Law-abiding } \\
\text { behavior } \\
\text { (Gesetzestreue) } \\
\text { Voluntary }\end{array}$ & $\begin{array}{c}\text { Paying church tax } \\
\text { (Kirchensteuer zahlen) }\end{array}$ \\
$\begin{array}{l}\text { Freedom of opinion } \\
\text { (Meinungsfreiheit) }\end{array}$ & Falsifying signatures & $\begin{array}{c}\text { commitment } \\
\text { (Unterschrift fälschen) }\end{array}$ & $\begin{array}{c}\text { Drug consumption } \\
\text { (Ehrenamtliches } \\
\text { Engagement) }\end{array}$ \\
\hline
\end{tabular}

